\title{
CRESCIMENTO E PRODUÇÃO DE MILHO FERTIRRIGADO COM BIOFERTILIZANTE COMPOSTO POR ÁGUAS AMARELAS E MANIPUEIRA
}

\author{
AUTOR: ROSEANE CARNEIRO DE OLIVEIRA \\ CO-AUTOR/ORIENTADOR: NARCISIO CABRAL DE ARAUJO
}

Resumo: Esta pesquisa objetivou analisar crescimento e produção de milho fertirrigado com solução
de biofertilizante produzido a partir de águas amarelas e manipueira. O experimento foi conduzido
em campo em área experimental da CEPLAC, Ilhéus, BA. Utilizou-se delineamento experimental em
blocos ao acaso, com quatro blocos e cinco tratamentos. Os tratamentos consistiram por fertirrigaçães
com doses crescentes de biofertilizante obtido a partir de águas amarelas e manipueira. Para avaliação
do crescimento, aos 36, 50 e 60 dias após a semeadura (DAS), foram analisadas: altura de planta (AP),
diâmetro caulinar (DC), número de folhas (NF) e massa fresca da parte aérea (MFPA). Para avaliação da
produção, foram analisados: número de fileiras de grãos por espiga (NFGE), número de grãos por fileira
(NGF), número de grãos por espiga (NGE), massa de 100 grãos (M100G) e massa de grãos por espiga
(MGE). De acordo com os resultados obtidos, constatou-se diferença significativa para: AP, DC e NF aos
50 DAS; AP, DC e MFPA aos 60 DAS; M100G, MGE e NFGE. O modelo de regressão que melhor se ajustou
a AP e NF aos 50 DAS, AP e MFPA aos 60 DAS e MGE foi o linear crescente. Para DC aos 50 e 60 DAS e
M100G o melhor modelo foi o quadrático crescente. Para NFGE o quadrático com decréscimo. As aplicaçães
das doses crescentes do biofertilizante proporcionaram crescimento e a produção do milho. O uso desse
biofertilizante testado pode ser utilizado na fertirrigação do milho em substituição a adubação mineral.

Palavras-chave: Saneamento ecológico, Urina humana, Zea mays L. 